\title{
Purification and Biochemical Characterization of Native and Pegylated Form of L-Asparaginase from Aspergillus terreus and Evaluation of Its Antiproliferative Activity
}

\author{
Claudio Battiston Loureiro ${ }^{1}$, Kleiton Silva Borges ${ }^{2}$, Augusto Faria Andrade ${ }^{2}$, \\ Luiz Gonzaga Tone ${ }^{2,3}$, Suraia Said ${ }^{*}$ \\ ${ }^{1}$ Departamento de Ciências Farmacêuticas, FCFRP-USP, Ribeirão Preto, Brazil \\ ${ }^{2}$ Departamento de Genética, FMRP-USP, Ribeirão Preto, Brazil \\ ${ }^{3}$ Departamento de Puericultura e Pediatria, FMRP-USP, Ribeirão Preto, Brazil \\ Email: *susaid@usp.br
}

Received January 20, 2012; revised March 2, 2012; accepted March 12, 2012

\begin{abstract}
L-asparaginase is a chemotherapeutic drug used in the treatment of lymphoblastic leukemia. In the present study, the extracellular L-asparaginase produced by strain (PC-1.7.A) of Aspergillus terreus was purified, characterized, and modified with polyethylene glycol. Moreover, its antiproliferative activity was evaluated. The apparent molecular weight of the enzyme was found to be $136 \mathrm{kDa}$. The optimal $\mathrm{pH}$ and temperature for the enzyme were $9.0^{\circ} \mathrm{C}$ and $40^{\circ} \mathrm{C}$, respectively. The enzyme retained $100 \%$ of the activity at $40^{\circ} \mathrm{C}$ for $120 \mathrm{~min}$. Pegylated L-asparaginase was more thermostable and more resistant to trypsin than native enzyme. Native L-asparaginase against human normal cells did not show cytotoxicity. However, in the leukemia cell lines RS4;11 and HL60 the antiproliferative effects of native L-asparaginase were observed after 96 and $72 \mathrm{~h}$ of incubation, respectively. For the first time, an L-asparaginase from fungus was evaluated as an antitumor agent in human cells lines and further investigations should be conducted to improve the knowledge about this enzyme.
\end{abstract}

Keywords: Aspergillus terreus; L-Asparaginase; Antineoplasic Activity; Leukemia

\section{Introduction}

The enzyme L-asparaginase (L-asparagine amino hydrolase, E.C. 3.5.1.1) is an important component in the treatment of pediatric acute lymphoblastic leukemia (ALL) and catalyzes the hydrolysis of asparagine and glutamine into aspartic acid and ammonia. This conversion provokes the asparagine starvation in the blood plasma and induces the death of malignant cells, since they are unable to synthesize asparagine and reduced levels of asparagine inhibits protein synthesis in leukemic cells [1]. Current studies of L-asparaginase therapy have also started in adults [2]. The effect and half-life of L-asparaginase depends on some factors such as antibody formation, plasmatic proteases, formation of asparagine via asparagine synthetase and microbial source [3]. Over the years, several bacterial L-asparaginases have been reported and only a few reports about L-asparaginase produced by filamentous fungi have been made. Among

"Corresponding author. these reports are the L-asparaginase production by $A s$ pergillus tamari, A. terreus [4], A. niger [5], A. nidulans [6], and in some yeast, but their antiproliferative activeties were not analyzed. Currently, there are three asparaginases preparations available for therapy, two of them are native and produced by the bacteria Escherichia coli and Erwinia chrysanthemi. The other one, also from $E$. coli is conjugated and its elimination half life is approximately six days, five times longer than the native $E$. coli and nine times longer than the Erwinia preparations $[2,7]$. The bacterial L-asparaginases are targets of antibodies and proteases, moreover side effects are observed during the treatment using this enzyme. Great efforts have been made to modify and immobilize these L-asparaginases in order to decrease their immunogenicity effects and increase their half-life. L-asparaginase from other sources, like eukaryotic microorganisms, should lead to an enzyme with less adverse effects. In this study, the extracellular L-asparaginase produced by Aspergillus terreus was purified, biochemically characterized, con- 
jugated with polyethylene glycol and the antiproliferative activity of native enzyme was evaluated against two leukemic cells lines.

\section{Materials and Methods}

\subsection{Microorganism}

Aspergillus terreus (strain PC-1.7.A) was isolated from Brazilian soil by Dr. S. Said and identified by Dra. C. M. S. Motta from Federal Pernambuco University (Laboratory of Taxonomy and Systematic of Fungi). The fungus has been maintained by weekly transfers on slants of PDA medium.

\subsection{L-Asparaginase Production}

Enzyme production was optimized in Czapek Dox's modified liquid medium in two steps: the pre-fermentation medium containing $0.2 \%(\mathrm{w} / \mathrm{v})$ glucose, $2 \%(\mathrm{w} / \mathrm{v})$ L-proline, $0.2 \%$ (w/v) $\mathrm{NH}_{4} \mathrm{NO}_{3}, 0.15 \%$ (w/v) $\mathrm{KH}_{2} \mathrm{PO}_{4}$, $0.05 \%(\mathrm{w} / \mathrm{v}) \mathrm{KCl}, 0.05 \%(\mathrm{w} / \mathrm{v}) \mathrm{MgSO}_{4} \cdot 7 \mathrm{H}_{2} \mathrm{O}$ and $0.001 \%$ (w/v) $\mathrm{ZnSO}_{4} \cdot 7 \mathrm{H}_{2} \mathrm{O}, \mathrm{FeSO}_{4} \cdot 7 \mathrm{H}_{2} \mathrm{O}$ and $\mathrm{CuSO}_{4} \cdot 5 \mathrm{H}_{2} \mathrm{O}$, the $\mathrm{pH}$ was adjusted to 8.5 with $\mathrm{KOH}$, this medium was inoculated with $1 \times 10^{7}$ spores $\mathrm{mL}^{-1}$ and incubated at 120 $\mathrm{rpm}$ for $17 \mathrm{~h}$ at $30^{\circ} \mathrm{C}$. The culture was filtrated; the mycelium was collected and inoculated in the fermentative medium, which was similar to the medium used in previous step except for the absence of $\mathrm{NH}_{4} \mathrm{NO}_{3}$. The culture was reincubated for 96 hours at the same previous conditions.

\subsection{L-Asparaginase and L-Glutaminase Assays}

L-asparaginase activity was determined according Drainas and Pateman [6] and modified as follows: $0.6 \mathrm{~mL} 20$ $\mathrm{mmol} \cdot \mathrm{L}^{-1}$ Tris-HCl buffer, $\mathrm{pH} 8.0 ; 0.2 \mathrm{~mL} 100 \mathrm{mmol} \cdot \mathrm{L}^{-1}$ stock L-asparagine solution; $0.2 \mathrm{~mL} 1 \mathrm{~mol} \cdot \mathrm{L}^{-1}$ stock hidroxylamine solution; and $1 \mathrm{~mL}$ culture broth were mixed and incubated at $37^{\circ} \mathrm{C}$ and $120 \mathrm{rpm}$. After $30 \mathrm{~min} 0.5 \mathrm{~mL}$ ferric chloride reagent $\left[10 \%(\mathrm{w} / \mathrm{v}) \mathrm{FeCl}_{3}\right.$ plus $5 \%(\mathrm{w} / \mathrm{v})$ trichloroacetic acid in $0.66 \mathrm{~mol} \cdot \mathrm{L}^{-1} \mathrm{HCl}$ ] was added. One unit of L-asparaginase is the amount of enzyme that releases $1 \mathrm{mmol} \mathrm{NH}_{3}$ or aspartic acid per minute at $37^{\circ} \mathrm{C}$ at the specific conditions just mentioned. L-glutaminase was assayed according to Imada et al. [8]. The reaction mixture contained $0.5 \mathrm{~mL}$ of $0.04 \mathrm{M}$ of L-glutamine; 0.5 $\mathrm{mL}$ of $0.5 \mathrm{M}$ Tris-HCl buffer; $\mathrm{pH}$ 7.2; $0.5-1.0 \mathrm{~mL}$ culture broth (concentrated or not) and distilled water a final volume of $2.0 \mathrm{~mL}$. It was incubated at $37^{\circ} \mathrm{C}$ for $30-60$ min. and the reaction was stopped with $0.5 \mathrm{~mL}$ of $1.5 \mathrm{M}$ of trichloroacetic acid. In fact $0.1 \mathrm{~mL}$ of mixture just mentioned and $0.2 \mathrm{~mL}$ of Nessler's reagent were added to $3.7 \mathrm{~mL}$ of distilled water. After $20 \mathrm{~min}$, the absorption was measured at $450 \mathrm{~nm}$. One L-glutaminase unit was defined as the amount of enzyme that liberates $1 \mu \mathrm{mol}$ of ammonia per $1 \mathrm{~min}$.

\subsection{Determination of Protein Concentration}

The concentration of protein was determined by the Bradford [9] method with bovine serum albumin as a standard.

\subsection{Separation and Purification of L-Asparaginase}

The extracellular L-asparaginase was purified in three chromatographic steps, and after each step, the fractions were analyzed for activity and absorbance at $280 \mathrm{~nm}$.

Step 1: The culture fluid was separated from mycelium by filtration. Then $900 \mathrm{~mL}$ was dialyzed against 5 $\mathrm{mmol} \cdot \mathrm{L}^{-1}$ Tris-HCl buffer, $\mathrm{pH} 8.0$ (buffer A) overnight at $4^{\circ} \mathrm{C}$, concentrated with polyethyleneglycol, and $20 \mathrm{~mL}$ were applied to a DEAE-Sepharose Fast Flow column $(2.5 \times 22.5 \mathrm{~cm})$ pre-equilibrated with $20 \mathrm{mmol} \cdot \mathrm{L}^{-1}$ Tris$\mathrm{HCl}$ buffer, $\mathrm{pH} 8.0$ (buffer B). The bound proteins were eluted by step-wise increases in $\mathrm{NaCl}(100$ and 150 $\left.\mathrm{mmol} \cdot \mathrm{L}^{-1}\right)$ at flow rate of $120 \mathrm{~mL} \cdot \mathrm{h}^{-1}$. Fractions $(5.0 \mathrm{~mL})$ were collected.

Step 2: The fractions with L-asparaginase collected from DEAE-Sepharose Fast Flow were pooled, dialyzed against buffer A, and loaded on a Sephacryl S-200 HR column $(1.0 \times 58.0 \mathrm{~cm})$. The protein elution was performed with the buffer B containing $150 \mathrm{mmol} \cdot \mathrm{L}^{-1}$ $\mathrm{NaCl}$ at a flow rate of $9.6 \mathrm{~mL} \cdot \mathrm{h}^{-1}$. Fractions $(2.0 \mathrm{~mL})$ were collected.

Step 3: The fractions from step 2 that contained L-asparaginase were pooled, dialyzed against buffer $\mathrm{A}$, and applied again on a Sephacryl S-200 HR column $(1.0 \times$ $5.8 \mathrm{~cm}$ ) however the flow rate was reduced at $6.0 \mathrm{~mL} \cdot \mathrm{h}^{-1}$. The fractions $(0.8 \mathrm{~mL})$ were pooled, concentrated with polyethyleneglycol, and dialyzed against buffer A overnight at $4^{\circ} \mathrm{C}$. The samples were assayed and used for further characterization.

\subsection{Modification of L-Asparaginase with Activated Polyethylene Glycol (PEG)}

The pegylated form of purified L-asparaginase from $A$. terreus was obtained according to Soares et al., [10] and adapted as follows: $2.5 \mathrm{~mL}$ of $50 \mathrm{mM}$ phosphate buffer $\mathrm{pH} 7.0$ containing $1 \mathrm{mg}$ L-asparaginase and $20 \mathrm{mg}$ activated m-PEG 5000 Da was maintained at $30^{\circ} \mathrm{C}$ for $2 \mathrm{~h}$ and after this time it was kept at $4^{\circ} \mathrm{C}$ overnight. Pegylated L-asparaginase was purified on a Sephacryl S$200 \mathrm{HR}$ column $(1.0 \times 58 \mathrm{~cm})$, equilibrated with buffer B and eluted with the same buffer containing $150 \mathrm{mmol} \cdot \mathrm{L}^{-1}$ $\mathrm{NaCl}$ at a flow rate of $6.0 \mathrm{~mL} \cdot \mathrm{h}^{-1}$.

\subsection{Electrophoresis Analysis}

Polyacrilamide gel electrophoresis (SDS-PAGE) as de- 
scribed by Laemmli [11] was performed using $4 \%$ (w/v) stacking gel and $7.5 \%(\mathrm{w} / \mathrm{v})$ acrylamide slab gel at a constant current of $20 \mathrm{~mA}$. Protein bands were stained with silver nitrate according to Blum et al. [12].

\subsection{Characterization of Purified and Pegylated form of L-Asparaginase}

The optimum values of $\mathrm{pH}$ and temperature of purified enzyme were determined over a $\mathrm{pH}$ range of $2.2-10.6$ (citrate-phosphate buffer [pH 2.2 - 7.8], Tris- $\mathrm{HCl}$ buffer [pH 8.2 - 9.0], and carbonate-bicarbonate buffer [pH 9.5 - 10.6]) and temperatures from $25^{\circ} \mathrm{C}$ to $60^{\circ} \mathrm{C}$. $\mathrm{Km}$ was determined from double reciprocal plots (Linewear-Burk) incubating the pure enzyme with different concentrations of substrate at temperature and $\mathrm{pH}$ optima. The molecular mass was estimated by chromatography on Sephacryl S-200 HR using different protein molecular weight markers: cytochrome C (12.4 kDa), $\alpha$-lactalbumin (14.2 kDa), bovine serum albumin ( $66 \mathrm{kDa})$, alcohol dehydrogenase $(150 \mathrm{kDa})$, and $\beta$-amylase $(200 \mathrm{kDa})$. The column was pre-equilibrated with buffer $\mathrm{B}$, the proteins were eluted with the same buffer containing $150 \mathrm{mmol} \cdot \mathrm{L}^{-1} \mathrm{NaCl}$ at a flow rate of $6.0 \mathrm{~mL} \cdot \mathrm{h}^{-1}$. The thermo stability of purified and pegylated L-asparaginase was determined by preincubating the enzymes in $100 \mathrm{mmol} \cdot \mathrm{L}^{-1}$ Tris-HCl buffer $(\mathrm{pH} 8.0)$ at different temperatures $\left(40^{\circ} \mathrm{C}, 50^{\circ} \mathrm{C}\right.$, and $\left.60^{\circ} \mathrm{C}\right)$ for $120 \mathrm{~min}$. Samples were collected at 15, 30, 60, 90, and $120 \mathrm{~min}$, and the residual activity was assayed. Proteolytic resistance was evaluated after digestion of 180 $\mu \mathrm{g}$ of pure asparaginase and modified with $60 \mu \mathrm{g}$ of bovine trypsin in a total volume of $1.0 \mathrm{ml}$ at $37^{\circ} \mathrm{C}$. Samples were collected from each solution at 5, 10, 15, 30, and 60 min and assayed for the residual activity. All the stability studies were repeated in triplicate and values are shown as mean $\pm \mathrm{SD}$.

\subsection{Cell Culture and Cell Preparation}

The human leukemia cell lines HL-60 (pre-myeloid leukemia) and RS4;11 (leukemia with lymphoid and myeloid characteristics, Stong et al. [13] were purchased from the American Type Culture Collection and were maintained in RPMI (GIBCO, USA) supplemented with $10 \%$ fetal calf serum, $100 \mathrm{U} / \mathrm{mL}$ penicillin and $100 \mu \mathrm{g} / \mathrm{mL}$ streptomycin. Human peripheral blood mononuclear cells (PBMC) were purified from heparinized venous blood drawn from healthy donors. PBMC were isolated by centrifugation on Ficoll-Paque (Pharmacia-LKB, Uppsala, Sweden) density gradients $(1.077 \mathrm{~g} / \mathrm{mL})$ at $1000 \mathrm{rpm}$ for $15 \mathrm{~min}$ at room temperature and subsequently resuspended in RPMI. All cell cultures were incubated at $37^{\circ} \mathrm{C}$ in a $5 \% \mathrm{CO}_{2}$ humidified atmosphere. The counting and cell viability tests were determined using the test of Trypan blue exclusion.

\subsection{Proliferation Assay}

Cells were seeded in 96-well plates at $1 \times 10^{4}$ cells per well. After $24 \mathrm{~h}, \mathrm{~L}$-asparaginase was added at concentrations of $12.5 \mu \mathrm{g} / \mathrm{mL}, 25 \mu \mathrm{g} / \mathrm{mL}, 50 \mu \mathrm{g} / \mathrm{mL}, 100 \mu \mathrm{g} / \mathrm{mL}$ and $200 \mu \mathrm{g} / \mathrm{mL}$. At different time points (48, 72, and $96 \mathrm{~h}$ ) of continuous drug exposure, $10 \mu \mathrm{l}$ of XTT dye $(3 \mathrm{mg} / \mathrm{mL})$ (XTT II; Roche Molecular Biochemicals, Indianapolis, IN) was added in each well. The plates were incubated for $2 \mathrm{~h}$ at $37^{\circ} \mathrm{C}$ and the formazan product was measured at $450 \mathrm{~nm}$ by using an iMark microplate reader (Bio-Rad Laboratories). The experiments were performed in triplicate in three independent sets. Values are shown as mean \pm SD. Cell survival was calculated by subtracting the background absorbance of media alone and then dividing the absorbance of test wells by the absorbance of the control (untreated) wells.

\section{Results}

\subsection{Biochemical Characterization of Native and Pegylated L-Asparaginase}

The purification of L-asparaginase was carried out by three steps with a final yield of $7.28 \%$ and a purification fold of 10.67 (Table 1, Figure 1). The molecular weight of the native enzyme determined by its mobility on the gel filtration column and SDS-PAGE was estimated to be $136 \mathrm{kDa}$ (Figure 2). The $\mathrm{Km}$ value of the native enzyme using asparagine as a substrate and determined from Lineweaver-Burk plot was found to be $2.42 \mathrm{mM}$ (Figure 3(a)). The optimum $\mathrm{pH}$ for enzyme was found to be 9.0 and at physiological $\mathrm{pH}$ the enzyme retained $70 \%$ of maximum activity (Figure 3(b)). L-asparaginase exhibited the highest levels of activity at $40^{\circ} \mathrm{C}$ (Figure 3(c)) and was stable at this temperature for until $120 \mathrm{~min}$. (Figure 3(d)). The Km value of the pegylated enzyme using asparagine as a substrate and determined from the Lineweaver-Burk plot was found to be $2.51 \mathrm{mM}$ (not shown).

The Pegylated-L-asparaginase retained $93 \%$ of the original activity from the native enzyme, and it clearly eluted as a separated peak from the native enzyme (Figure 4(a)). It showed more resistance to proteolytic degradation than the native L-asparaginase maintaining about $45 \%$ of initial activity after $30 \mathrm{~min}$ in the presence of trypsin (Figure 4(b)). Both native and pegylated enzymes were stable after incubation for more than $60 \mathrm{~min}$ at $40^{\circ} \mathrm{C}$, but the pegylated L-asparaginase maintained $75 \%$ of enzymatic activity at $50^{\circ} \mathrm{C}$ for 15 min while the native enzyme maintained only $13 \%$ at this condition (Figures 3(d) and 4(c)).

\subsection{Cytotoxic Activity}

In the assay against human normal cells the L-asparaginase did not show cytotoxicity (Figure 5(a)). The data 
Table 1. Purification steps of L-asparaginase produced by A. terreus.

\begin{tabular}{|c|c|c|c|c|c|}
\hline Purification steps & Total protein (mg) & Total activity (U) & Specific activity (U/mg) & Fold purification & Yield \% \\
\hline Crude extract & 23.10 & 139.70 & 6.04 & 1.00 & 100 \\
\hline Step 1 & 2.19 & 48.69 & 22.23 & 3.68 & 34.85 \\
\hline Step 2 & 0.37 & 17.18 & 46.70 & 7.72 & 12.30 \\
\hline Step 3 & 0.16 & 10.16 & 64.55 & 10.67 & 7.28 \\
\hline
\end{tabular}

Step 1: DEAE-Sepharose; Step 2: Sephacryl S-200 HR; Step 3: Sephacryl S-200 HR.

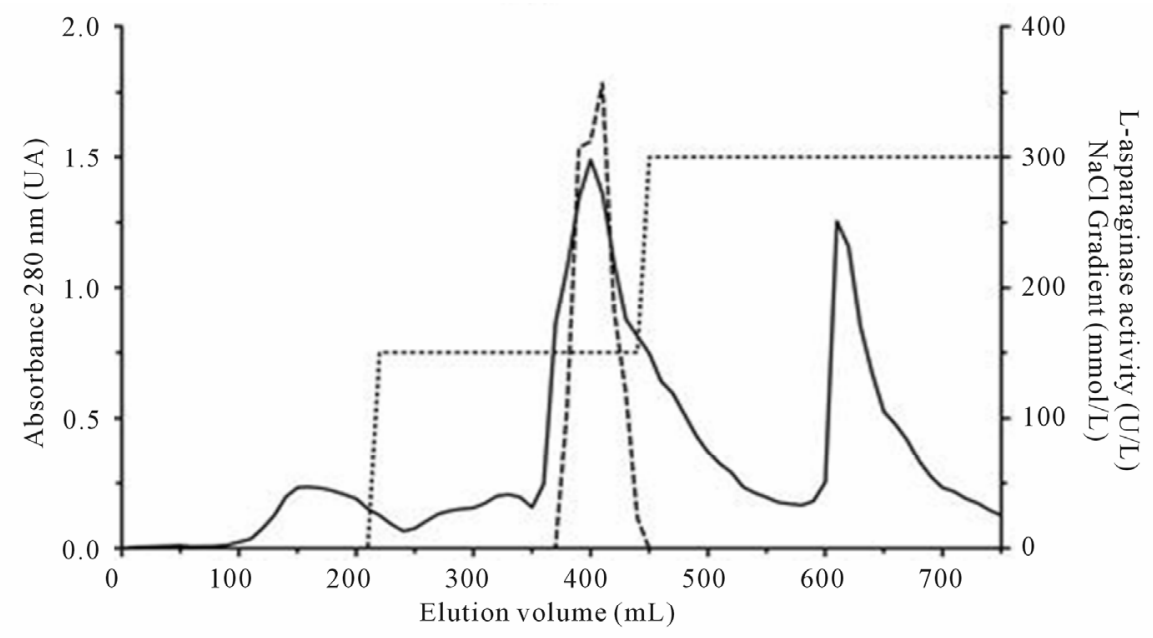

(a)
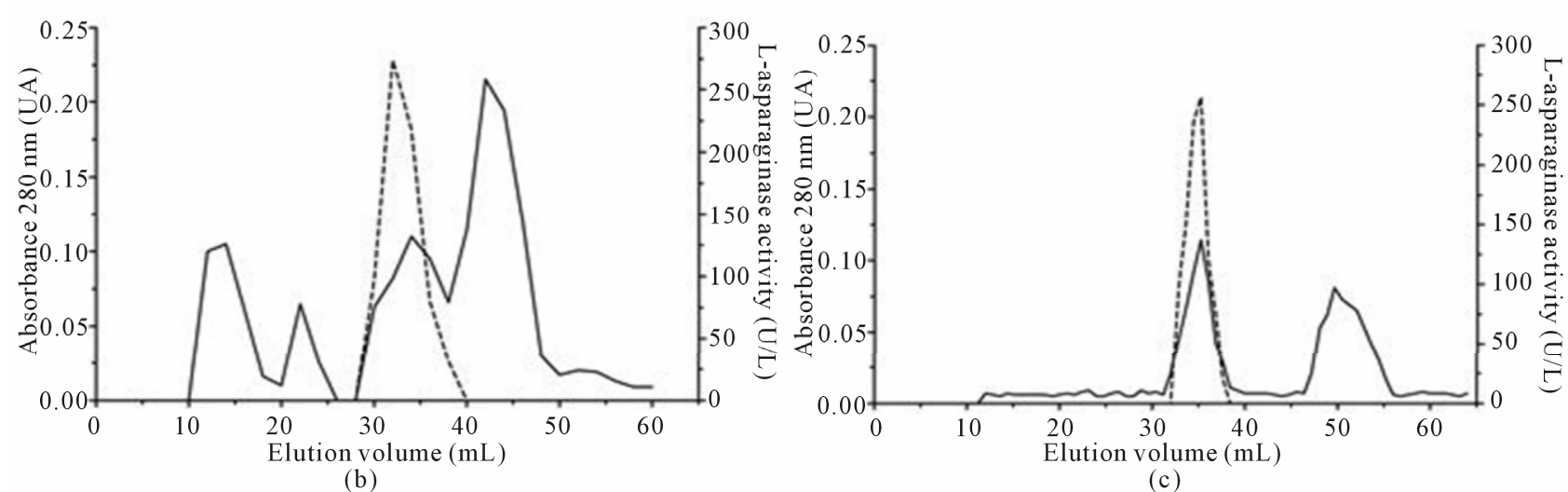

(b)

(c)

Figure 1. Chromatographic separation of L-asparaginase produced by A. terreus. (a) The crude extract was dialyzed, concentrated and applied to DEAE-Sepharose which was eluted in $20 \mathrm{mmol} \cdot \mathrm{L}^{-1}$ Tris-HCl $\mathrm{pH} 8.0$ under a flow of $120 \mathrm{~mL} \cdot \mathrm{h}^{-1}$; (b) The fractions containing enzyme activity were pooled and applied to gel filtration column of Sephacryl S-200HR with the same buffer under a flow of $9.6 \mathrm{~mL} \cdot \mathrm{h}^{-1}$; (c) The fractions containing enzyme activity were combined and applied to gel filtration column of Sephacryl S-200HR with the same buffer under a flow of $6.0 \mathrm{~mL} \cdot \mathrm{h}^{-1}$. The fractions collected were analyzed by absorbance in $280 \mathrm{~nm}(-)$, enzyme activity (---) and step-wise $\mathrm{NaCl}(\cdots \cdots)$.

obtained from this assay using RS4;11 cells indicated a dose and time-response effect and the drug dose required to cause $50 \%$ reduction in cell viability in this cell was of $100 \mu \mathrm{g} \cdot \mathrm{mL}^{-1}$ after $96 \mathrm{~h}$ of incubation (Figure 5(b)). The leukemic cells HL-60 incubated with L-asparaginase had their cell viability by $50 \%$ in a concentration of 200 $\mu \mathrm{g} \cdot \mathrm{mL}^{-1}$ in an incubation time of $72 \mathrm{~h}$, but after this time, the cell viability increased again (Figure 5(c)).

\section{Discussion}

Since the first observations that some L-asparaginases demonstrate anti-leukemic activity, great progress has been made in the therapeutic protocols that combine L-asparaginases with other chemotherapeutic drugs. However, the favorable effects achieved with L-asparaginase in leukemia treatment are accompanied of the undesired side effects as thrombosis, pancreatitis, renal 


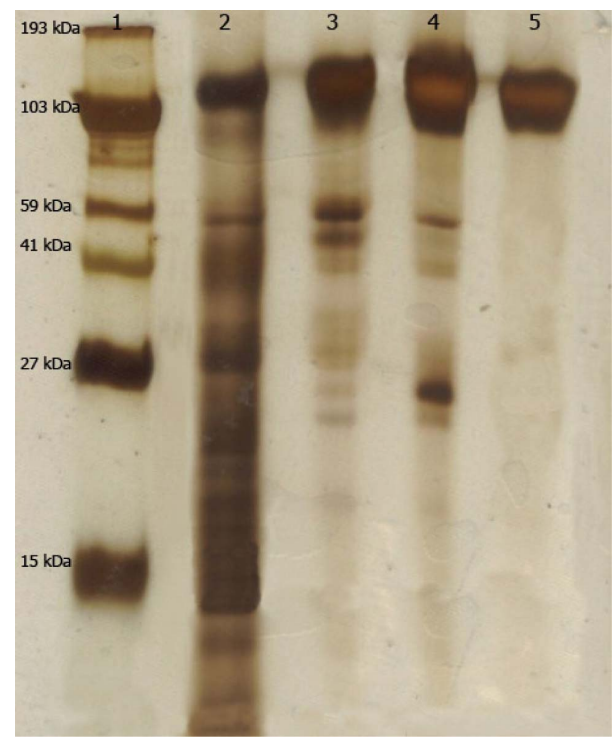

Figure 2. Polyacrylamide gel electrophoresis of purified L-asparaginase from A. terreus. Protein bands were stained with silver nitrate. Lane 1: molecular weight markers; Lane 2: Crude extract; Lane 3: Fractions contains L-asparaginase activity from step 1; Lane 4: Fractions contains L-asparaginase activity from step 2; Lane 5: Fractions contains L-asparaginase activity from step 3 .

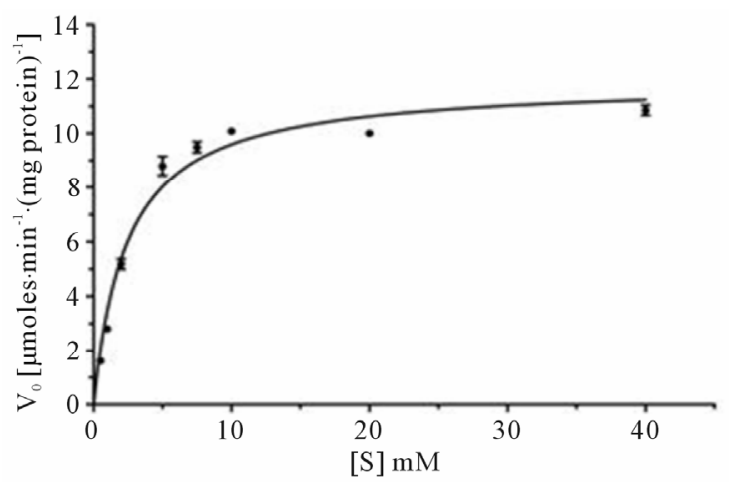

(a)

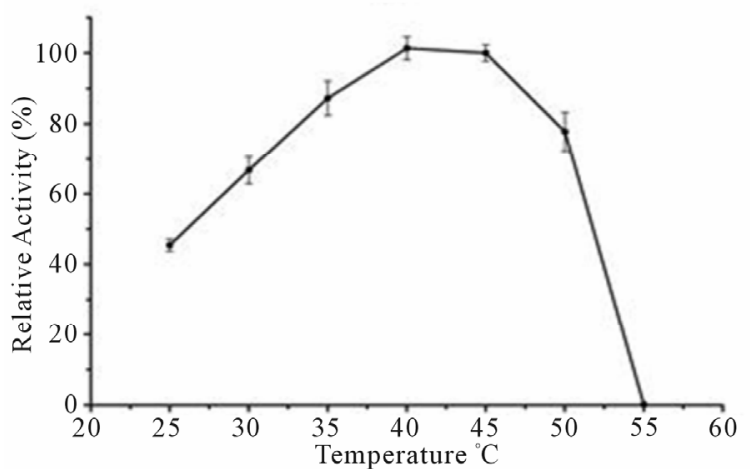

(c) complications, liver damage among others. For this reason, several reports has showed different enzyme formulations and new sources of L-asparaginase included those from eukaryotic organisms, to find less toxic enzymes that also show suitable antineoplastic effects. Our studies of L-asparaginase produced by A. terreus (PC-1.7.A) started determining of the good conditions for its production and the its highest levels were detected if L-proline $2 \%$ was the nitrogen source [14] and it is in accordance with the results reported by Sarquis et al. [4]. The molecular weight found here for the enzyme was $136 \mathrm{kDa}$, similar value has been described to $E$. coli L-asparaginase, $134 \mathrm{kDa}$. However, the $\mathrm{Km}$ value of native L-asparaginase was found to be $2.42 \mathrm{mM}$, while that from $E$. coli is $0.0125 \mathrm{mM}$ [15]. It shows that the L-asparaginase from $A$. terreus has less affinity for asparagine than Lasparaginase from $E$. coli but the L-asparaginase from $A$. terreus was capable to inhibit the prolifiration of leukemia cells. According to Panosyan et al. [16] the effective deamination of glutamine by L-asparaginase appears to contribute to the decrease of asparagine depletion by depriving the asparagine synthetase of glutamine, the precursor asparagine biosynthesis. Bacterial L-asparaginase, used in therapeutic protocols, has low glutaminase activity

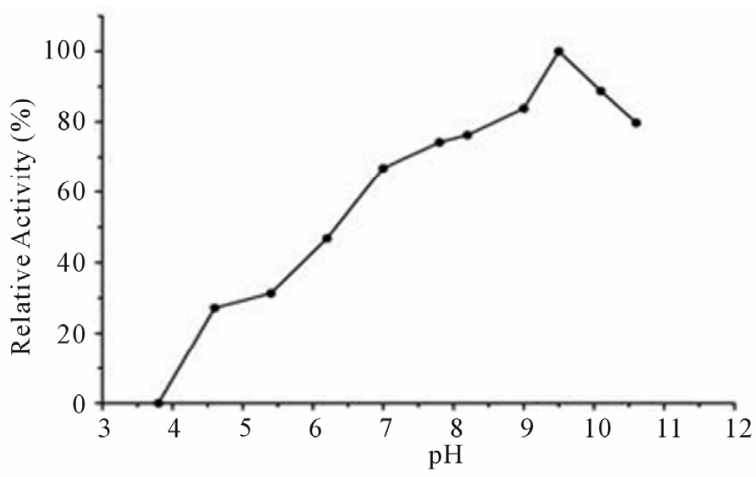

(b)

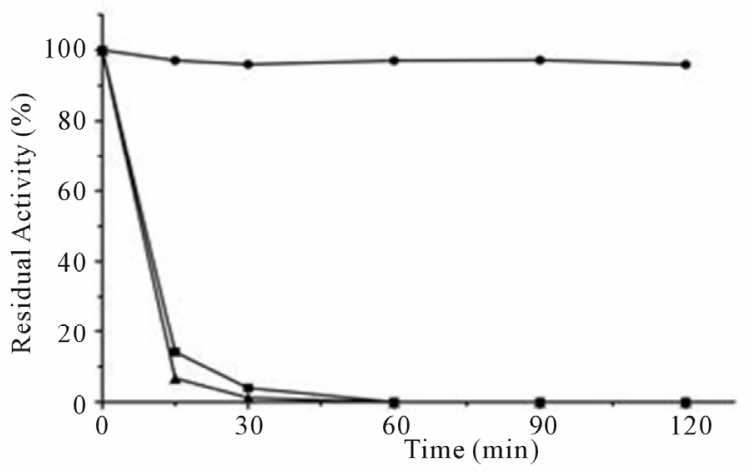

(d)

Figure 3. Characterization of L-asparaginase obtained from A. terreus. (a) The $\mathrm{Km}$ value was determined by incubate the native enzyme at different concentrations of asparagines; (b) The optimal $\mathrm{pH}$ of activity was assessed by measuring the enzyme activity at different pHs ranging from 3.8 to 10.6; (c) The optimal temperature for activity was assessed by measuring the enzyme activity at different temperatures between 25 and $60^{\circ} \mathrm{C}$; (d) For thermostability test the native enzyme was incubated at different temperatures, $40^{\circ} \mathrm{C}(-\bullet-), 50^{\circ} \mathrm{C}(--)$ and $60^{\circ} \mathrm{C}(-\Delta-)$ for a period of up to $120 \mathrm{~min}$. 


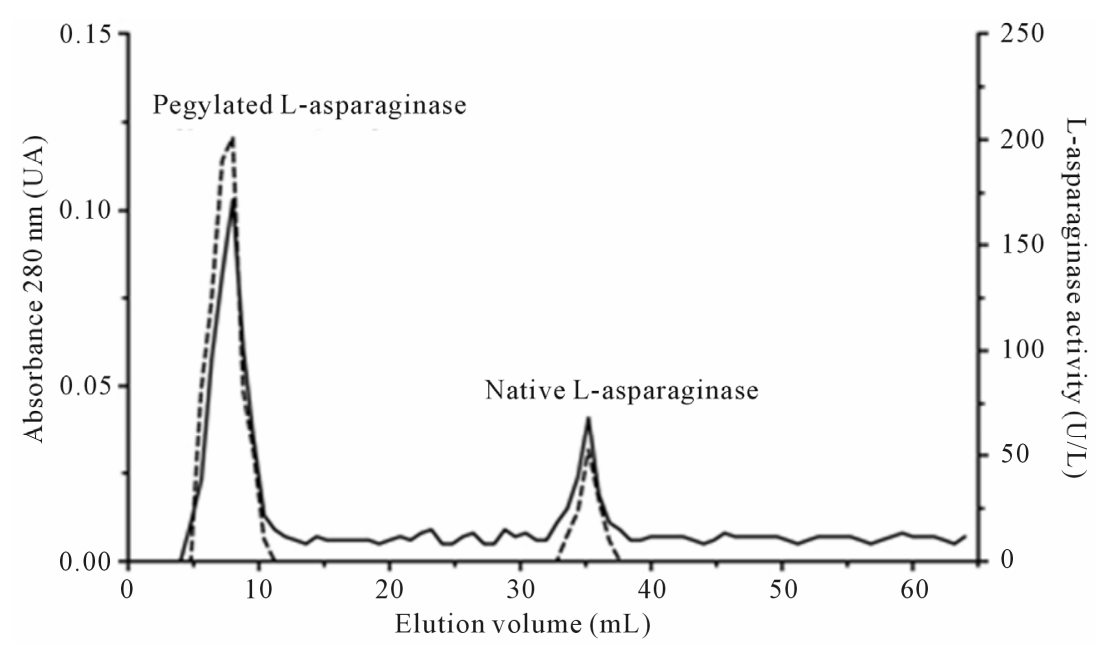

(a)

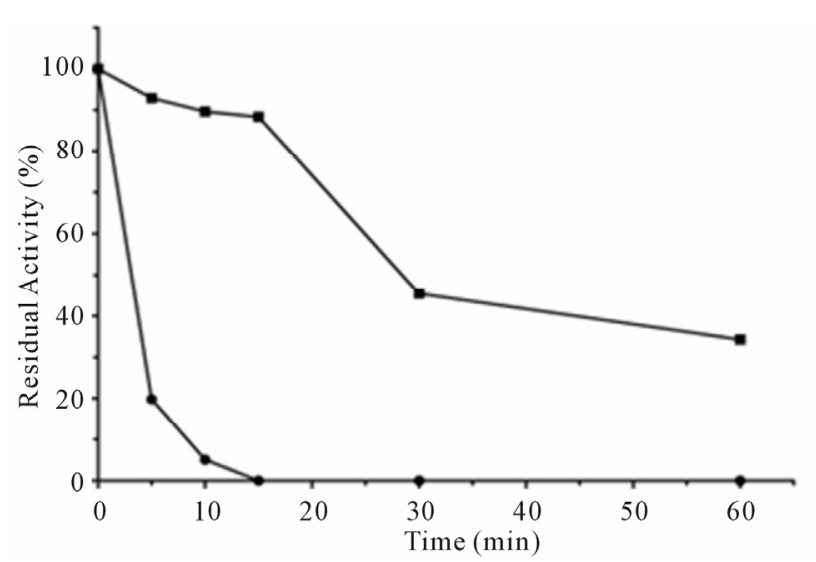

(b)

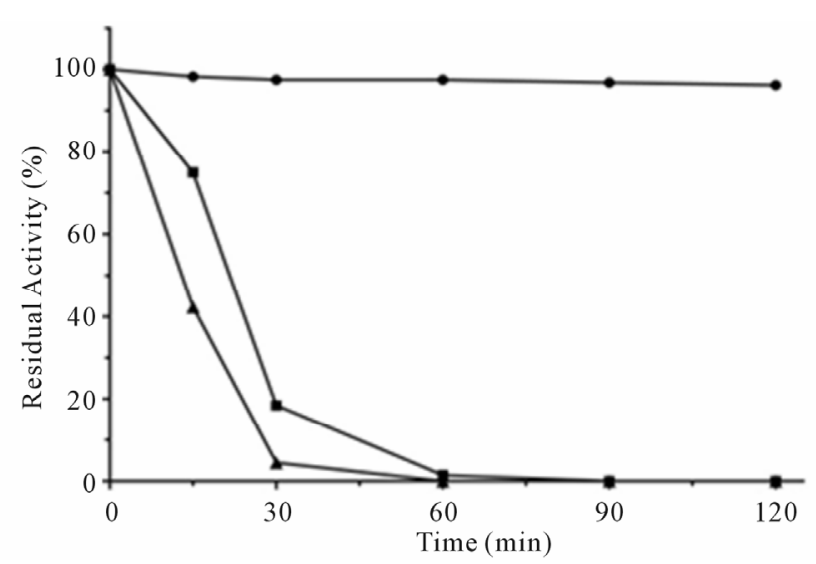

(c)

Figure 4. Partial characterization of pegylated L-asparaginase. (a) Chromatographic separation between pegylated L-asparaginase and native enzyme. The enzyme mixture was applied to gel filtration column of Sephacryl S-200HR, pre-equilibrated with $20 \mathrm{mM}$ Tris-HCl pH 8.0 containing $150 \mathrm{mM}$ NaCl eluted under flow of $6.0 \mathrm{~mL} \cdot \mathrm{h}^{-1}$. Fractions of $0.8 \mathrm{~mL}$ were collected and analyzed at A280 (-) and enzyme activity determined (----); (b) Stability of the pegylated and native L-asparaginase against enzymatic proteolysis. $180 \mu \mathrm{g}$ of native L-asparaginase (- $\bullet-)$ or pegylated (- - -) were incubated with $60 \mu \mathrm{g}$ of bovine trypsin, for 60 minutes; (c) The thermostability of pegylated L-asparaginase. The enzyme was incubated at different temperatures, $40^{\circ} \mathrm{C}(-\bullet-), 50^{\circ} \mathrm{C}(-\square-)$ and $60^{\circ} \mathrm{C}(-\Delta-)$ for a period of up to $120 \mathrm{~min}$.

but toxicity reactions are attributed to this activity [17, 18]. Herein L-glutaminase activity was not detected in crude enzyme (concentrated or not) produced by $A$. terreus (PC-1.7.A) even after $60 \mathrm{~min}$ of the reaction. This should contribute significantly to diminution of side effects and it may be helpful in clinical practice.

A manner of reducing the immunogenicity of L-asparaginase is covalently linking the enzyme with PEG, what may also become the enzyme more resistant to leukemic lysosomal cysteine proteases. It is important to know that the half-lives of $E$. coli asparaginase linked to PEG are longer than the native enzyme $[3,17]$. Herein the pegylated-L-asparaginase was resistant to trypsin, a cysteine protease, and was more thermostable than the native enzyme, as well maintained $93 \%$ of the original activity.
The antiproliferative effects of L-asparaginase produced by $A$. terreus (PC-1.7.A) was evaluated after 24, 48, 72 and $96 \mathrm{~h}$ of incubation of two leukemia cell lines (RS4;11 and HL-60) and PBMC. There was no effect on proliferation of PBMC. This L-asparaginase caused 50\% reduction in cell viability after $72 \mathrm{~h}$ on the cell line HL-60 and after $96 \mathrm{~h}$ on the cell line RS4;11 (Figure 5). Interestingly, cell proliferation of HL-60 cell increased after $72 \mathrm{~h}$ and this can be associated with multiple adaptive cellular mechanisms. Studies have demonstrated increased asparagine synthetase (AS) expression in cells treated with L-asparaginase. It has been hypothesized that this elevated activity allows these leukemia cells to become resistant to the treatment. Moreover, other adaptive processes may provide a substrate to asparagine synthetase such as aspartate or glutamine, which derive 


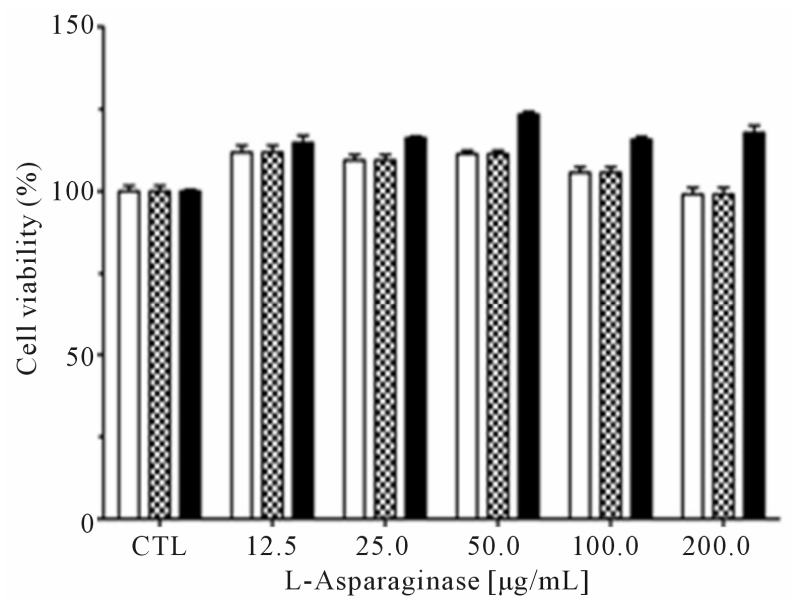

(a)

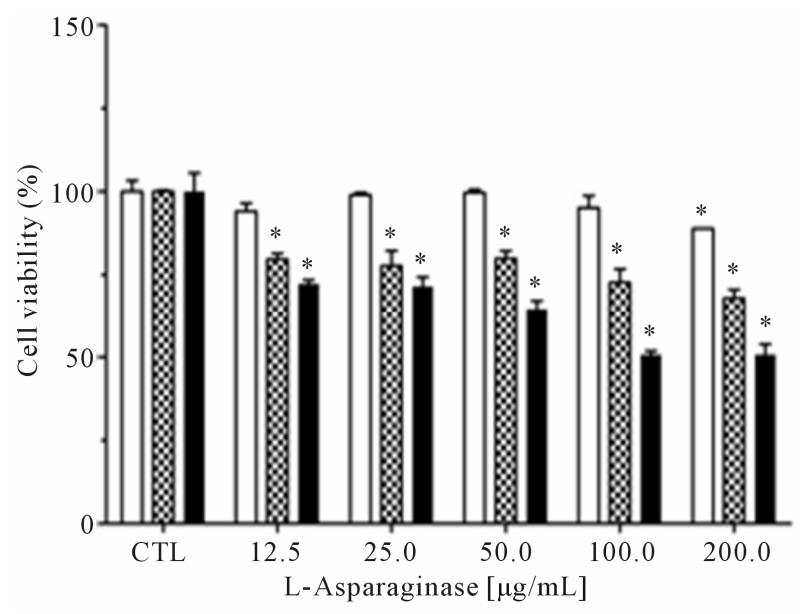

(b)

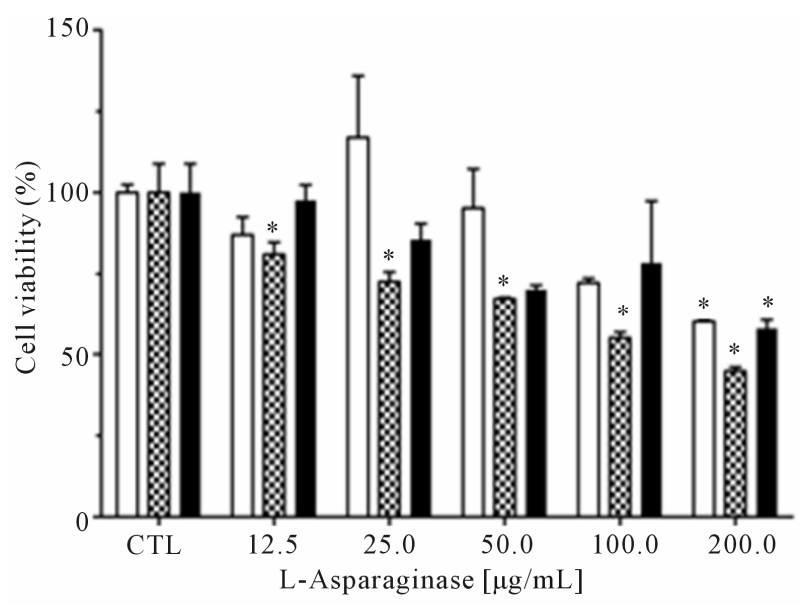

(c)

Figure 5. Cell viability of leukemic cells after treatment with purified L-asparaginase from Aspergillus terreus. Cells $(1 \times$ $10^{4}$ cell/well) mononuclear (a); leukemic RS4;11 (b) and leukemic HL-60 (c), were incubated in 96-well plates and treated with different concentrations of $L$-asparaginase for $48 \mathrm{hr}(\square), 72 \mathrm{hr}(\mathrm{MU})$ and $96 \mathrm{hr}$ ( $\square$ ). The tests were analyzed by the XTT method. The results represent mean \pm SEM. Dunnett test (CTL-control group without treatment). from intracellular and extracellular sources [19,20].

The results of the present study clearly indicate that the L-asparaginase produced by A. terreus (PC-1.7.A) has a molecular weight similar to the $E$. coli, does not present glutaminase activity and displays good results after pegylation. Moreover, this L-asparaginase caused antiproliferative effects on two leukemia cell lines. Altogether, these data prompted further investigations into the L-asparaginase produced by $A$. terreus (PC-1.7.A).

\section{Acknowledgements}

This work is part of a thesis submitted by Claudio B. Loureiro to Faculdade de Ciências Farmacêuticas de Ribeirão Preto, Universidade de São Paulo, in partial fulfillment of the requeriments for the Master's degree. CBL received a master fellowship from Coordenação de Aperfeiçoamento de Pessoal de Nível Superior (CAPES).

\section{REFERENCES}

[1] U. K. Narta, S. S. Kanwar and W. Azmi, "Pharmacological and Clinical Evaluation of L-Asparaginase in the Treatment of Leukemia," Critical Reviews in Oncology/Hematology, Vol. 61, No. 3, 2007, pp. 208-221. doi:10.1016/j.critrevonc.2006.07.009

[2] S. Patil, J. Coutsouvelis and A. Spencer, "Asparaginase in the Management of Adult Acute Lymphoblastic Leukemia: Is It Used Appropriately?" Cancer Treatment Reviews, Vol. 37, No. 3, 2011, pp. 202-207. doi:10.1016/j.ctrv.2010.08.002

[3] J. C. Panetta, A. Gajjar, N. Hijiya, L. J. Hak, C. Cheng, W. Liu, C. H. Pui and M. V. Relling, "Comparison of Native E. coli and PEG-Asparaginase Pharmacokinetics and Pharmacodynamics in Pediatric Acute Lymphoblastic Leukemia," Clinical Pharmacology and Therapeutics, Vol. 86, No. 6, 2009, pp. 651-658. doi:10.1038/clpt.2009.162

[4] M. I. Sarquis, E. M. Oliveira, A. S. Santos and G. L. Costa, "Production of L-Asparaginase by Filamentous Fungi," Memorias do Instituto Oswaldo Cruz, Vol. 99, No. 5, 2004, pp. 489-492. doi:10.1590/S0074-02762004000500005

[5] A. Mishra, "Production of L-Asparaginase, an Anticancer Agent, from Aspergillus niger Using Agricultural Waste in Solid State Fermentation," Applied Biochemistry and Biotechnology, Vol. 135, No. 1, 2006, pp. 33-42. doi:10.1385/ABAB:135:1:33

[6] C. Drainas and J. A. Pateman, "L-Asparaginase Activity in the Fungus Aspergillus nidulans," Biochemical Society Transactions, Vol. 41, 1977, pp. 1365-1371.

[7] R. Pieters, S. P. Hunger, J. Boos, C. Rizzari, L. Silverman, A. Baruchel, N. Goekbuget, M. Schrappe and Ching-Hon. Pui, "L-Asparaginase Treatment in Acute Lymphoblastic Leukemia," Cancer, Vol. 117, No. 2, 2011, pp. 239-249. doi:10.1002/cncr.25489

[8] A. Imada, S. Igarasi, K. Nakahama and M. Isono, "Asparaginase and Glutaminase Activities of Microorganisms," Journal Genetics Microbiology, Vol. 76, No. 1, 1973, pp. 85-99. 
[9] M. Bradford, "A Rapid and Sensitive Method for the Quantification of Microgram Quanties of Protein Utilizing the Principle of Protein Dye Binding," Analitical Biochemistry, Vol. 72, No. 1-2, 1976, pp. 248-254. doi:10.1016/0003-2697(76)90527-3

[10] A. L. Soares, G. M. Guimarães, B. Polakiewicz, R. N. M. Pitombo and J. Abrahão-Neto, "Effects of Polyethylene Glycol Attachment on Physicochemical and Biological Stability of E. coli L-Asparaginase," International Journal of Pharmaceutics. Vol. 237, No. 1-2, 2002, pp. 163170. doi:10.1016/S0378-5173(02)00046-7

[11] U. K. Laemmli, "Cleavage of Structural Proteins during the Assembly of the Head of Bacteriophage T4," Nature, Vol. 227, No. 5259, 1970, pp. 680-685. doi: $10.1038 / 227680 \mathrm{a} 0$

[12] H. Blum, H. Beier and H. J. Gross, "Improved Silver Staining of Plant Proteins, RNA and DNA in Polyacrylamide Gels," Electrophoresis, Vol. 8, No. 2, 1987, pp. 9399. doi:10.1002/elps.1150080203

[13] R. C. Stong, S. J. Korsmeyer, J. L. Parkin, D. C. Arthur and J. H. Kersey, "Human Acute Leukemia Cell Line with the t(4:11) Chromosomal Rearrangement Exhibits B Lineage and Monocytic Characteristics," Blood, Vol. 65, No.1, 1985, pp. 21-31.

[14] V. C. Foster and S. Said, "The Influence of Nitrogen Source on L-Asparaginase Production by Strain Isolated from Soil," VII Seminário Brasileiro de Tecnologia Enzimática, Caxias do Sul, 21-24 May 2006, p. 124.

[15] V. I. Avramis and E. H. Panosyan, "Pharmacokinetic/Pharmacodynamic Relationships of Asparaginase Formulations:
The Past, the Present and Recommendations for the Future," Clinical Pharmacokinetics, Vol. 44, No. 4, 2005, pp. 367-393.

[16] E. H. Panosyan, R. S. Grigoryan, I. A. Ayramis, N. L. Seibel, P. S Gaynon, S. E. Siegel, H. J. Finger and V. I. Ayramis, "Deamination of Glutamine Is a Prerequisite for Optimal Asparagine Deamination by Asparaginases in Vivo (CCG-1961)," Anticancer Research, Vol. 24, No. 2C, 2004, pp. 1121-1125.

[17] G. Ollenschlager, E. Roth, W. Linkescht, S. Jansen, A. Simmel and B. Modder, "Asparaginase-Induced Derangements of Glutamine Metabolism: The Pathogenetic Basis for Some Drug-Related Side-Effects," European Journal of Clinical Investigation, Vol. 18, No. 5, 1988, pp. 512516. doi:10.1111/j.1365-2362.1988.tb01049.x

[18] M. N. Offman, M. Krol, N. Patel, S. Krishnan, J. Z. Liu, V. Saha and P. A. Bates, "Rational Engineering of LAsparaginase Reveals Importance of Dualactivity for Cancer Cell Toxicity," Blood, Vol. 117, No. 5, 2011, pp. 1614-1621. doi:10.1182/blood-2010-07-298422

[19] A. M. Aslanian, B. S. Fletcher and M. S. Kilberg, “Asparagine Synthetase Expression Alone Is Sufficient to Induce L-Asparaginase Resistance in MOLT-4 Human Leukaemia Cells," Biochemical Journal, Vol. 357, No. Pt 1, 2001, pp. 321-328. doi:10.1042/0264-6021:3570321

[20] A, M. Aslanian and M. S. Kilberg, "Multiple Adaptive Mechanisms Affect Asparagine Synthetase Substrate Availability in Asparaginase-Resistant MOLT-4 Leukaemia Cells," Biochemical Journal, Vol. 358, No. Pt1, 2001, pp. 59-67. doi:10.1042/0264-6021:3580059 